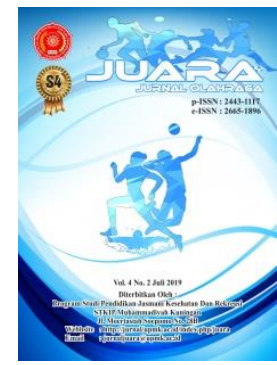

Penerapan Metode Progresif Terhadap Hasil Belajar Keterampilan Handspring di Alat Meja Lompat

\title{
Application of Progressive Method on Handspring Skill Learning Outcomes in Vaulting Table
}

Fegie Rizkia Mulyana ${ }^{1}$, Ridwan Gumilar ${ }^{2}$

1,2 Faculty of Teacher Training and Education, Universitas Siliwangi, Jl. Siliwangi No.24, Kahuripan, Kec. Tawang, Tasikmalaya, Jawa Barat 46115, Indonesia

email: fegierizkiamulyana@unsil.ac.id ${ }^{1}, \underline{\text { ridwangumilar@unsil.ac.id }}^{2}$

\section{Info Artikel}

Sejarah Artikel:

Diterima 15 Agustus 2019

Disetujui 22 November 2019

Dipublikasikan 09 Desember 2019

\section{Keywords:}

Progressive method, handspring learning, outcomes

\begin{abstract}
Abstrak
Dalam mata kuliah Pembelajaran Senam II, terdapat berbagai kendala yang sering dialami ketika proses pembelajaran berlangsung. Diantaranya kesulitan Dosen dalam menyampaikan materi pembelajaran, lemahnya pemahaman serta daya tangkap mahasiswa dalam proses pembelajaran sehingga berdampak pada nilai dan hasil belajar yang diperoleh pada keterampilan handspring di alat meja lompat. Tujuan dari penelitian ini yaitu untuk meningkatkan aktivitas dan hasil belajar mahasiswa serta mengetahui peningkatan penerapan metode progresif terhadap hasil belajar keterampilan handspring di alat meja lompat. Metode yang digunakan dalam penelitian ini yaitu penelitian tindakan (action research). Hasil dari penelitian tindakan ini yaitu adanya peningkatan kualitas hasil belajar mahasiswa. Pada siklus pertama didapat prosentase ketuntasan belajar $85 \%$ hasil ini didapat karena pada tahap ini masih terdapat kekurangan yaitu pada fase layangan kedua dikarenakan masih kurangnya pengalaman belajar gerak, lemahnya tolakan kaki sehingga mempengaruhi pada ketinggian layangan serta fase pendaratan. Pada siklus II mengalami peningkatan dengan prosentase ketuntasan belajar 98\%. Hal ini menandakan bahwa penerapan metode progresif memberikan pengaruh yang berarti terhadap peningkatan hasil belajar keterampilan handspring di alat meja lompat.
\end{abstract}

\footnotetext{
Abstract

In the gymnastics learning II, a variety of obstacles are often experienced during the learning process. The issues consist of the difficulties of lecturers to deliver learning materials, students' lack of understanding and processing the information during learning process that affect to their grade and learning outcomes of handspring skills on the vault. The purpose of this study is to improve student activities and learning outcomes and to increase in the application of progressive methods to the learning outcomes of handspring skills on the vault. The method used in this research is action research. The results of this action research are an
} 
increase in the quality of student learning outcomes. In the first cycle the percentage of mastery learning obtained $85 \%$ of this result is obtained because at this time it is still lacking in the second kite phase that still requires motion learning experience, the weakness of foot repulsion is greatly increased at the height of the kite and landing phase. In cycle II, there is an increase in the learning outcomes with a percentage of mastery learning 98\%. This indicates that the method of progressive application gives meaning to the improvement in learning outcomes of handspring skills on the vault.

(C) 2020 Fegie Rizkia Mulyana, Ridwan Gumilar

Under the license CC BY-SA 4.0

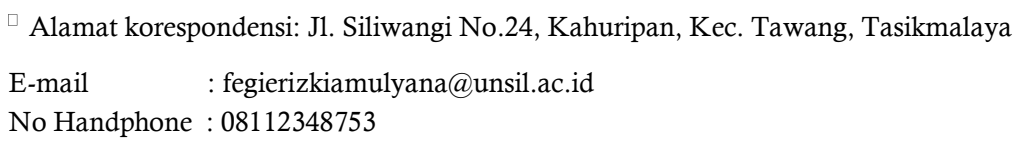

\section{PENDAHULUAN}

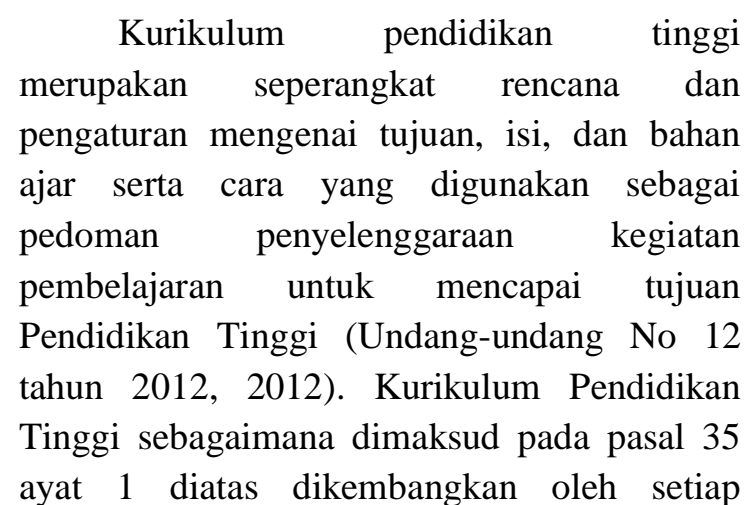
Perguruan Tinggi dengan mengacu pada Standar Nasional Pendidikan Tinggi untuk setiap Program Studi yang mencakup pengembangan kecerdasan intelektual, akhlak mulia, dan keterampilan. Tersurat dari pasal diatas, didalam kurikulum Jurusan Pendidikan Jasmani Universitas Siliwangi terdapat matakuliah Pembelajaran Senam II yang didalam proses pembelajarannya terdapat berbagai kesulitan yang sering dialami Dosen dalam menyampaikan materi pembelajaran senam, diantaranya seperti antusias mahasiswa, keberanian mahasiswa serta lemahnya pemahaman dan daya tangkap mahasiswa dalam proses pembelajaran Senam II sehingga berdampak pada hasil belajar Pembelajaran Senam II. Permasalahan yang sama pun diungkapkan dalam penelitian (Ridwan, Febriyanti, \& Wijaya, 2017) dalam pelaksanaan pembelajaran praktik terdapat kendala yang dihadapi dalam melaksanakan pembelajaran perkuliahan, seperti tidak adanya meja lompat yang sesuai dengan aturan ketinggian yang diakui, yaitu $135 \mathrm{~cm}$ untuk putra dan $125 \mathrm{~cm}$ untuk putri, rasa takutnya mahasiswa untuk melakukan gerakan handspring dan tingkat keamanan peralatan tersebut.

Pada umumnya "kesulitan" merupakan suatu kondisi tertentu yang ditandai dengan adanya hambatan-hambatan dalam kegiatan mencapai tujuan. Kesulitan belajar dapat diartikan sebagai suatu kondisi dalam suatu proses belajar yang ditandai adanya hambatanhambatan tertentu untuk mencapai hasil belajar. (Pingge, 2016).

Adapun hasil belajar menurut (Negara, 2014) merupakan suatu puncak proses belajar. Hasil belajar tersebut terjadi terutama berkat evaluasi guru. Sejalan dengan pengertian tersebut, menurut (Mudjiono, 2013) Hasil belajar merupakan hasil dari suatu interaksi tindak belajar dan mengajar. Penilaian hasil belajar adalah proses untuk mendapatkan informasi tentang prestasi atau kinerja peserta didik. Hasil penilaian di gunakan untuk evaluasi terhadap ketuntasan belajar peserta didik dalam aktifitas proses pembelajaran (Gani, 2012).

Dengan demikian hasil belajar adalah suatu keberhasilan yang dicapai setelah melewati pengalaman belajar. Konten materi dalam perkuliahan pembelajaran senam II 
disusun secara sistematis, teknik-teknik lanjutan ini sudah tergolong pada teknik yang terbilang komplek. Teknik yang dipelajari di matakuliah pembelajaran senam II sudah menggunakan lecutan, lentingan, lompatan, seperti teknik dasar handspring di lantai, round off, flic-fliac, salto dan teknik dasar handspring di meja lompat. Antusias dan kemampuan yang ditunjukan mahasiswa sangatlah bervariatif pada waktu pembelajaran. Dikarenakan gerakan-gerakan pada senam lantai merupakan gerakan kontinyu atau diskrit, maksudnya terdiri dari sikap awal, sikap pelaksanaan dan sikap akhir yang saling berhubungan. Ketika sikap awal ataupun sikap pelaksanaanya belum dikuasai akan mempengaruhi pada sikap dan gerakan selanjutnya.

Terkait dengan keterampilan handspring (Marcovic, 2012) mengemukakan Dalam senam, handspring depan adalah salah satu elemen kunci akrobat koneksi lebih lanjut dengan elemen akrobatik lainnya, dengan dilakukan rotasi sekitar sumbu depan tubuh. Elemen ini adalah bagian integral dari persiapan dalam seri akrobatik. Hal ini dapat dilakukan dari posisi awal yang berbeda di mana tujuan utamanya adalah untuk mengubah gerakan linear tubuh menjadi rotasi, dengan kehilangan minimal kecepatan horizontal serta prasyarat dasar untuk menolak dan fase implementasi penerbangan yang berhasil. Keterampilan handspring dimulai dengan fase lepas landas atau take off dari papan tolak, dimana pesenam menolak dengan kakinya. Hasil tolakan yang memadai di fase layangan pertama, dengan tujuan untuk mencapai posisi yang optimal dengan menempatkan tangan diatas meja lompat untuk menyiapkan ke tahap tolakan. Fase tolakan yang selanjutnya mengarah pada fase layangan kedua, fase pendaratan mengikuti pada fase layangan kedua, dimana pesenam harus mendarat pada posisi tegak (Heinen, Vinken, Jeraj, \& Velentzas, 2013).
Sedangkan unsur-unsur atau teknik yang harus dikuasai mahasiswa dalam mempelajari lompatan handspring pada meja lompat yaitu; lari cepat, tolakan, layangan pertama, tumpuan di meja, layangan kedua dan mendarat. Beberapa unsur tersebut tentulah membutuhkan metode yang tepat untuk memberikan pengajaran kepada mahasiswa, waktu atau pengelaman belajar yang cukup untuk mengulang kembali tugas gerak yang diberikan, dan yang terpenting didalam pembelajaran senam faktor keselamatan menjadi faktor yang paling utama selain perasaan aman dan nyaman yang harus dimiliki setiap mahasiswa atau peserta didik dalam proses pembelajaran. Dilihat dari sarana dan prasarananya, dalam matakuliah pembelajaran Senam II sudah terdapat dua buah meja lompat (vaulting table), 2 buah papan tolak (springboard), serta beberapa jenis matras tebal dan tipis yang digunakan untuk pendaratan. Melihat kondisi tersebut sudah barang tentu peralatan yang ada sudah menunjang terhadap proses pembelajaran. Namun yang menjadi permasalahan selama ini cara mengajar yang diberikan tidak jauh dari penggunaan metode klasikal. Sehingga setiap penggalan-penggalan materi tidak dikuasai secara utuh. Menelaah beberapa metode mengajar, Penulis memiliki asumsi bahwa untuk meningkatkan hasil belajar handspring di meja lompat yaitu dengan menggunakan metode progresif. Metode progresif (progressive method) adalah cara mengajar di mana bahan latihan atau keterampilan dibagi dalam beberapa unit atau bagian (Daharis, 2018). Terkait dengan rumitnya keterampilan handspring di meja lompat, perlu adanya pemecahan materi ajar supaya mahasiswa lebih mudah dalam mempelajari dan memahami setiap penggalan geraknya. Metode progresif ini sangat cocok digunakan dalam pembelajaran senam, dalam hal metode hanya metode progresif yang ditampilkan, karena dianggap sangat cocok dengan jenis keterampilan senam, yang umumnya 
merupakan keterampilan diskrit (jelas awal dan akhir gerakannya). Pada tahap pertama, latihan hanya melibatkan satu bagian keterampilan yang dianggap penting (inti) yang selalu ditekankan dan diulang - ulang. Pada tahap kedua, bagian pertama digabung dengan bagian kedua sehingga menampil kan pola gerak yang lebih besar. Pada tahap ketiga, bagian satu dan bagian dua digabung lagi dengan bagian tiga, yang menunjukkan pola keterampilan yang semakin lengkap. Demikian seterusnya sehingga keseluruhan bagian yang tersisa akhirnya tergabung secara keseluruhan. Kelebihan dari metode progresif yaitu memberikan kemudahan dalam proses belajar apalagi dalam mempelajari teknik yang kompleks, selain itu rangkaian gerak bisa dipelajari dan dipahami lebih detail dengan cara membagi materi ajar menjadi beberapa bagian sesuai dengan kebutuhan dan kemampuan mahasiswa.

Hal ini diperkuat dengan hasil penelitian terdahulu yang dilakukan oleh (Suryani, 2018) pembelajaran senam kayang menggunakan metode progresif dapat meningkat dari siklus ke siklus serta aktivitas siswa menjadi lebih baik dalam mengikuti pembelajaran dan gerak senam kayang yang dilakukan oleh siswa menjadi lebih baik. Selain meningkatkan aktivitas belajar, metode progresif juga memberikan pengaruh terhadap motivasi belajar siswa pada pembelajaran senam (Syahbana, 2014). Hal ini sejalan dengan hasil penelitian (Whardana, 2013) menunjukkan bahwa, metode progresif dapat meningkatkan pemahaman mahasiswa, mampu merangkaikan tahapan pertahapan gerak yang diberikan sehingga teknik yang dipelajari dapat dilakukan lebih baik dari sebelumnya sehingga memberi kontribusi yang signifikan terhadap peningkatan hasil belajar senam.

Berdasarkan hasil penelitian yang relevan, penulis tertarik untuk membuat langkah-langkah pembelajaran senam ketanggkasan menggunakan alat, yaitu teknik dasar handspring dialat meja lompat (vaulting table) dengan menerapkan metode progresif dalam proses pembelajaran. Berbeda dengan penelitian-penelitian sebelumnya yang hanya meneliti gerak dasar roll, backroll dan brught di nomor lantai saja. Diharapkan langkahlangkah pembelajaran handspring dialat meja lompat berbasis metode progresif ini bisa memudahkan serta menjadi salah satu referensi bagi guru ataupun dosen dalam mengelola pembelajaran senam.

\section{METODE}

Metode yang digunakan dalam penelitian ini yaitu metode penelitian tindakan (action research). Penelitian tindakan disajikan sebagai proses penyelidikan siklus dan berulang yang memandu persiapan dan proses pembelajaran guru (Stringer, 2010). Penelitian tindakan menggabungkan kegiatan penelitian atau pengumpulan data dengan penggunaan hasil penelitian atau pengumpulan data serta kegiatannya dilakukan secara timbal balik membentuk spiral: rencana, tindakan, pengamatan dan refleksi. Asumsi yang menjadi dasar pelaksanaan penelitian tindakan yaitu ; dalam pengalaman sendiri yang konkrit, melalui pengamatan dan refleksi dalam pengalaman tersebut, melalui pembentukan konsep abstrak dan generalisasi, dan dengan menguji implikasi konsep dalam situasi baru (Sukmadinata, 2011).

Desain penelitian yang digunakan dalam penelitian ini yaitu memakai model spiral Kurt Lewin, yaitu "planning, acting, observing, reflecting, then re-planning, acting again, observing again, reflecting again (Kemmis \& Taggart, 2014). Subjek dalam penelitian ini adalah mahasiswa Pendidikan Jasmani yang mengontrak matakuliah Pembelajaran Senam II yaitu mahasiswa kelas D angkatan 2018 yang berjumlah 40 orang.

Teknik pengumpulan data dalam penelitian ini dilalukan dengan cara observasi dan tes keterampilan handspring dimeja lompat. Observasi dilakukan untuk 
mengetahui kesulitan yang dialami mahasiswa ataupun yang dialami Dosen saat memberikan materi perkuliahan. Sebelum mengadakan penelitian, peneliti terlebih dahulu mengadakan observasi untuk mengamati sejauh mana mahasiswa menguasai beberapa teknik dasar senam dan sejauh mana kendala yang dialami dosen dalam penyampaian materi ajar, khususnya keterampilan handspring di meja lompat (vaulting table). Adapun tes keterampilan handspring dilakukan untuk mengukur kemampuan mahasiswa sejauh mana peningkatan keterampilan handspring di meja lompat (vaulting table) setelah diberikan pembelajaran menggunakan metode progresif.

Data akan dianalisis dengan menggunakan statistik deskriptif yaitu menggunakan rubrik penilaian yang dituangkan dalam RPS (Rencana Pembelajaran Semester) dan hasilnya berupa nilai pencapaian ketuntasan belajar berdasarkan pedoman akademik.

\section{HASIL DAN PEMBAHASAN Hasil}

Berdasarkan hasil observasi dan analisis data dilapangan ketika proses pembelajaran handspring di alat meja lompat dengan menggunakan metode progresif, keberhasilan belajar mahasiswa mencapai $85 \%$ dari jumlah mahasiswa sebanyak 40 orang. Dengan rincian sebagai berikut; mahasiswa yang mencapai prestasi belajar sangat baik, tidak ada $(0 \%)$, mahasiswa yang mencapai prestasi belajar baik sebanyak 1 orang (2,5\%), mahasiswa yang mencapai prestasi belajar cukup sebanyak 33 orang $(82,5 \%)$, mahasiswa yang mencapai prestasi belajar kurang sebanyak 6 orang $(15 \%)$, dan mahasiswa yang mencapai prestasi belajar sangat kurang, tidak ada $(0 \%)$.

Tabel 1. Hasil Belajar Keterampilan Handspring dialat Meja Lompat Pada Siklus 1

\begin{tabular}{cccc}
\hline Prestasi belajar & Nilai & $\begin{array}{c}\text { Ketuntasan } \\
\text { belajar }\end{array}$ & Presentase \\
\hline Sangat baik & $81-100$ & - & - \\
Baik & $61-80$ & 1 orang & $2,5 \%$ \\
Cukup & $41-60$ & 33 orang & $82,5 \%$ \\
Kurang & $21-40$ & 6 Orang & $15 \%$ \\
Sangat kurang & $0-20$ & - & - \\
\hline
\end{tabular}

Skor rata-rata mahasiswa yang didapat dari hasil belajar handspring dialat meja lompat pada siklus I adalah 48,44 dari hasil skor tertinggi mahasiswa dikelas $\mathrm{D}$ yaitu 68,75. Berdasarkan penilaian hasil belajar dalam pedoman akademik, jumlah mahasiswa yang dikatakan tuntas sebanyak 34 orang (85\%), dan dikatakan belum tuntas sebanyak 6 orang $(15 \%)$ dari jumlah subjek 40 orang. Kemampuan mahasiswa dalam mempelajari teknik dasar handspring di alat meja lompat sudah dikatakan tuntas walaupun dengan rentang skor dibatas bawah, namun masih terdapat kekurangan yaitu pada fase layangan dan fase pendaratan.

Tabel 2. Hasil Belajar Keterampilan Handspring dialat Meja Lompat Pada Siklus 2

\begin{tabular}{cccc}
\hline Prestasi belajar & Nilai & $\begin{array}{c}\text { Ketuntasan } \\
\text { belajar }\end{array}$ & Presentase \\
\hline Sangat baik & $81-100$ & 4 orang & $10 \%$ \\
Baik & $61-80$ & - & - \\
Cukup & $41-60$ & 35 orang & $87,5 \%$ \\
Kurang & $21-40$ & 1 orang & $2,5 \%$ \\
Sangat kurang & $0-20$ & - & - \\
\hline
\end{tabular}


Berdasarkan hasil pengamatan yang dilakukan pada siklus II ini menunjukkan bahwa adanya peningkatan hasil belajar keterampilan handspring dialat meja lompat dibandingkan pembelajaran pada siklus I. Dari 40 orang mahasiswa yang sudah mencapai ketuntasan belajar yaitu sebanyak 39 orang, dan jika diprosentasekan adalah 98\%. Ini sudah menunjukan peningkatan hasil belajar yang signifikan dari siklus sebelumnya.

Skor rata-rata mahasiswa yang didapat dari hasil belajar handspring dialat meja lompat pada siklus II adalah 55,31 dari hasil skor tertinggi mahasiswa dikelas D yaitu 81,25. Kemampuan mahasiswa dalam mempelajari teknik dasar handspring di alat meja lompat sudah dikatakan tuntas walaupun ada salah satu mahasiswa yang belum mencapai ketuntasan. Pada fase layangan dan pendaratan yang awalnya kurang dikuasai mahasiswa setelah diberi perlakuan dan tindakan di siklus II hasilnya meningkat signifikan.

\section{Pembahasan}

Hasil belajar yang baik tidak terlepas dari proses pembelajaran yang baik pula. Namun seorang pengajar baik guru ataupun dosen harus bisa merancang pembelajaran sesuai dengan kebutuhan materi yang diajarkan dan kebutuhan peserta didik. Salah satunya dengan cara memilih metode yang tepat dalam proses pembelajaran. Metode progresif yang diterapkan dalam penelitian ini bermaksud untuk mengetahui apakah bisa meningkatkan pemahaman belajar serta hasil belajar mahasiswa dibandingkan dengan aktivitas pembelajaran sebelumnya dengan menggunakan metode klasikal seperti metode bagian dan lain-lain. Kelebihan dari metode progresif ini bisa memudahkan mahasiswa dalam mempelajari keterampilan gerak dasar senam yang kompleks. Teknisnya dengan cara memecah bahan ajar menjadi beberapa bagian serta menggabungkan bagian per bagian yang nantinya menjadi teknik yang utuh. Dengan cara tersebut mahasiswa bisa lebih mudah dalam mempelajari dan memahami teknik dasar secara sistematis. Selain kelebihan yang dipaparkan penulis diatas, penerapan metode progresif selalu menekankan apa yang menjadi inti dari gerakan tersebut dan selalu menggabungkan antara bagian perbagian sehingga nantinya menjadi rangkian utuh dan dapat dilakukan secara luwes, lancar dan harmonis (Utomo, 2015).

Berdasarkan hasil dari beberapa penelitian dapat disimpulkan bahwa metode progresif bisa meningkatkan pemahaman, motivasi mahasiswa, aktivitas belajar mahasiswa serta hasil belajar khususnya pada materi senam lantai. Tidak ditemukan kekurangan pada metode ini hanya saja pengajar harus bisa menentukan bagian-bagian materi yang akan dipecah dan diajarkan agar sesuai dengan kebutuhan pembelajaran. Selain penerapan metode progresif, penguatan, motivasi dan evaluasi diperlukan pula dalam proses pembelajaran agar ketiga ranah pembelajaran (kognitif, afektif dan psikomotor) bisa tercapai sesuai dengan tujuan pembelajaran.

\section{SIMPULAN}

Berdasarkan hasil pengamatan dilapangan, dapat disimpulkan bahwa penerapan metode progresif dalam pembelajaran senam dapat meningkatkan pemahaman belajar mahasiswa dan hasil belajar mahasiswa khususnya keterampilan handspring di alat meja lompat (vaulting table). Metode progresif memberikan kemudahan baik untuk Dosen dalam hal menyampaikan materi ataupun bagi mahasiswa dalam mempelajari keterampilan senam. Dengan demikian berdampak positif bagi aktivitas serta motivasi mahasiswa dalam proses pembelajaran sehingga bisa meningkatkan hasil belajar mahasiswa khususnya keterampilan handspring dialat meja lompat. 


\section{UCAPAN TERIMA KASIH}

Selama penyusunan penelitian ini banyak rintangan dan kesulitan yang penulis hadapi, namun dalam pelaksanaannya penulis tidak terlepas dari bantuan beberapa pihak yang memberikan motivasi, masukan, bimbingan serta memfasilitasi demi kelancaran dan kemudahan dalam proses penelitian ini. Untuk itu penulis mengucapkan banyak terima kasih kepada semua pihak yang tidak bisa penulis sebutkan satu persatu. Semoga kebaikannya bisa menjadi amal baik dan mendapatkan ridho-Nya. Aamiin

\section{DAFTAR PUSTAKA}

Daharis. (2018). Perbedaan Pengaruh Metode Bantuan Alat Dan Metode Senam Guling Depan. Journal Sport Area, 3(2), 121130. https://doi.org/https://doi.org/10.25299/s portarea.2018.vol3(2).1603

Gani, A. A. (2012). Models of Learning Outcomes Assessment of Physical, Sport and Health Education in Junior High School. Https://Journal.Unnes.Ac.Id, 1(2). Retrieved from https://journal.unnes.ac.id/sju/index.php/ jpes/article/view/804

Heinen, T., Vinken, P. M., Jeraj, D., \& Velentzas, K. (2013). Research Quarterly for Exercise and Sport Movement Regulation of Handsprings on Vault. Research Quarterly for Exercise and Sport, (March 2013), 37-41. https://doi.org/10.1080/02701367.2013.7 62300

Kemmis, S., \& Taggart, R. M. (2014). The Action Research Planner. New York: Springer Singapore Heidelberg New York Dordrecht London.

Marcovic, K. Z. (2012). Biomechanical Evaluation of Exercises for Performing a Forward Handspring. Journal of Human Kinetics, 34. https://doi.org/10.2478/v10078-012-
0060-2

Mudjiono, D. dan. (2013). Belajar dan Pembelajaran. Jakarta: Rineka Cipta.

Negara, K. T. P. (2014). Kooperatif Tipe NHT untuk Meningkatkan Aktivitas dan Hasil Belajar Berguling Senam Lantai. EJournal PJKR Universitas Pendidikan Ganesha, 1.

Pingge, H. D. (2016). Faktor yang Mempengaruhi Hasil Belajar Siswa Sekolah Dasar di Kecamatan Kota Tambolaka. Jurnal Pendidikan Sekolah Dasar Desember, 2(1). Retrieved from https://media.neliti.com/media/publicatio ns/71489-ID-faktor-yang-

mempengaruhi-hasil-belajar-s.pdf

Ridwan, M., Febriyanti, I., \& Wijaya, A. (2017). Meningkatkan Keterampilan Gerakan Handpring Dengan Pembelajaran Melalui Gaya Mengajar Inkuiri Pendidikan Olahraga Universitas Negeri Surabaya. Jurnal Pembelajaran Olahraga, 3(1).

Stringer, E. T. (2010). Integrating Teaching, Learning, and Action Research. SAGE Publications, Inc.

Sukmadinata. (2011). Metode Penelitian Pendidikan. Bandung: Remaja Rosdakarya.

Suryani, Y. (2018). Meningkatkan Pembelajaran Senam Kayang Menggunakan Metode Progresif. Ejournal.Upi.Edu, 1(1). Retrieved from http://ejournal.upi.edu/index.php/SpoRTI VE/article/view/13393

Syahbana, F. N. (2014). Pengaruh Metode Pembelajaran Progresif Terhadap Motivasi Belajar Siswa SMK Negeri 3 Cimahi kelas XI Perhotelan 3 Pada Pembelajaran Aktivitas Ritmik Universitas Pendidikan Indonesia | repository.upi.edu perpustakaan.upi.edu.

Repository.Upi.Edu. Retrieved from http://repository.upi.edu/11159/

Undang-undang No 12 tahun 2012 (2012). 
Utomo, T. B. (2015). Meningkatkan Hasil Belajar Senam Lantai Roll Belakang Jongkok Melalui Metode Pembelajaran Progresif.
Whardana, R. (2013). Meningkatkan Hasil Belajar Roll Depan Senam Lantai Melalui Metode Progresif. Retrieved from https://eprints.uns.ac.id/14013/ 